\title{
Occupational risk factors for female breast cancer:
}

\section{a review}

\author{
Mark S Goldberg, France Labrèche
}

\begin{abstract}
Objectives-Although progress has been made in identifying personal risk factors and in improving treatment for female breast cancer, incidence rates continue to increase. With women now occupying a sizable fraction of the workforce, it is worth inquiring whether there are occupational risk factors for breast cancer. This is a review of occupational studies on female breast cancer.
\end{abstract}

Methods-Suitable reports and published articles with associations of female breast cancer and occupation were identified from technical reports, by searching the MEDLINE bibliographic data base, and by reviewing each paper on cancer that was published in 20 major journals during the period from about 1971-94.

Results-A total of 115 studies were identified; 19 studies relied exclusively on data collected for administrative purposes, and there were four incident case-control studies and 92 cohort studies. Although data for individual industries, occupations, and exposures were sparse, there was limited evidence of an association with employment in the pharmaceutical industry and among cosmetologists and beauticians. Associations were also found for chemists and occupations with possible exposure to extremely low frequency electromagnetic fields, but potential methodological weaknesses preclude drawing any definite conclusions. There was little support for increased risks among textiles workers, dry cleaning workers, and nuclear industry workers.

Conclusions-Few high quality occupational studies directed specifically toward women have been carried out to allow the unambiguous identification of occupational risk factors for breast cancer. It is suggested that investigations that account for non-occupational risk factors and that assess exposure in a more detailed way be carried out. One strategy already suggested is to conduct population based, case-control studies in which subjects are interviewed about their occupational histories and exposure to chemical and physical agents which are then attributed from the job descriptions by a team of experts. These studies can then be supplemented when necessary with cohort studies of specific populations.

(Occup Environ Med 1996;53:145-156)
Keywords: cancer female breast; occupational exposure; epidemiology; literature review

Breast cancer in western societies affects almost one in 10 women during their lifetime ${ }^{1}$ and is the leading cause of death from cancer in women. ${ }^{2}$ Over the past quarter century, the focus of research has been to improve treatments and to identify personal risk factors, such as family history of cancer and reproductive factors. ${ }^{3}$ Observations on reproductive factors have led to the hypothesis that breast cancer is caused by early and extended exposures to hormonal oestrogen and progesterone. ${ }^{4}$ Environmental risk factors have also been studied, but not as extensively. Exposure to ionising radiation has been shown to be clearly associated with a risk of breast cancer. ${ }^{5}$ Other environmental exposures have been investigated recently, including consumption of alcohol, ${ }^{6}$ exposure to persistent organochlorine compounds, ${ }^{7}$ and dietary fat, ${ }^{8}$ although results are controversial. ${ }^{6910}$

Against this large research effort is the unfortunate fact that incidence rates in most western societies have continued to increase over the past few decades. ${ }^{211-13}$ The reasons for these increases are largely unknown, but could be related to early detection in mass screening programmes, ${ }^{14}$ to temporal changes in accepted and suspected risk factors, to changes in the pathological definition of breast cancer, or to an artifact of detecting "histologically malignant but biologically benign" tumours $^{15}$ (although this seems doubtful ${ }^{13}$ ), or to other unidentified risk factors. It is likely that the accepted risk factors cannot account for a large fraction of cases or for all of the growth in incidences rates. ${ }^{16}$

As women have taken a more active role in the workforce since the $1960 \mathrm{~s},{ }^{17}$ it is possible that the secular increases in incidence rates may be related in part to exposure to carcinogens in the workplace. Although the occupational setting has not been studied with the intensity given to personal risk factors, interest in this field has increased. ${ }^{18}$ In considering new avenues of research, it is timely to provide a review of the current state of knowledge of the occupational environment. We therefore present a summary of results for breast cancer from occupational studies conducted within the past 25 years.

\section{Materials}

Reports and published articles with the potential for investigating associations of female 
Table 1 fournals and time periods covered by this review

\begin{tabular}{|c|c|}
\hline fournal & Calendar period \\
\hline $\begin{array}{l}\text { American Industrial Hygiene Association Journal } \\
\text { American Journal of Epidemiology } \\
\text { American Journal of Industrial Medicine } \\
\text { Annals of Epidemiology } \\
\text { Annals of Occupational Hygiene } \\
\text { Applied Occupational and Environmental Hygiene } \\
\text { Archives of Environmental Health } \\
\text { British Journal of Cancer, with Supplements } \\
\text { British Journal of Industrial Medicine } \\
\text { Cancer } \\
\text { Cancer Causes and Control } \\
\text { Cancer Research } \\
\text { Epidemiology } \\
\text { International Archives of Occupational and Environmental Health } \\
\text { International Journal of Cancer, with Supplements } \\
\text { International Journal of Epidemiology } \\
\text { Journal of Occupational Medicine } \\
\text { Journal of the National Cancer Institute } \\
\text { Journal of Toxicology and Environmental Health } \\
\text { Scandinavian Journal of Work Environment and Health }\end{array}$ & $\begin{array}{l}1987-94 \\
1965-94^{\star} \\
1971-94^{\star} \\
1991-\text { mid-1994 } \\
1987-92 \\
1988-\text { mid-1994 } \\
1965-94^{\star} \\
1980-\text { mid-1994 } \\
1965-94^{\star} \\
1985-94 \\
1990-94 \\
1985-\text { mid-1994 } \\
1990-94 \\
1975-93 \\
1985-93 \\
1971-\text { mid-1994 } \\
1965-\text { mid-1994 } \\
1971-\text { mid-1994^ } \\
1987-\text { mid-1994 } \\
1971-\text { mid-1993* }\end{array}$ \\
\hline
\end{tabular}

^Review for 1971-90 carried out by Hoar Zahm et al. ${ }^{19} 20$

breast cancer and occupation were identified by searching the MEDLINE bibliographic data base, and by reviewing each paper on cancer that was published in 20 major journals during the period from about 1971 to about mid1994 (table 1). We benefited from the earlier review carried out by Hoar Zahm and colleagues $^{19} 20$ of papers in eight journals published between 1971 and 1990. Excluded from consideration were studies of the radium dial painters because they have limited relevance to women's occupations after the second world war.

A total of 147 reports from 115 independent studies, including non-peer reviewed technical reports, ${ }^{2933444561}$ were reviewed (table 2). Studies were classified by type of

Table 2 Distribution of the types of studies included in this review

\begin{tabular}{lcc}
\hline Type of study (abbreviation) & Reports ${ }^{\star} n$ & References $^{\star \star}$ \\
\hline Studies based on administrative data: & & \\
Mortality studies: & 4 & $21-24$ \\
Standardised mortality ratio (SMR) & 15 & $25-40$ \\
Proportional mortality (PMR) & 3 & $41-43$ \\
Mortality odds ratio (MOR) & 3 & 44,45 \\
Combination SMR/PMR & 1 & 46 \\
Combination PMR/MOR & 1 & 47 \\
Combination SMR/MOR & & $51-50$ \\
Incidence studies: & 3 & 59 \\
Proportional incidence ratio (PIR) & 8 & 60 \\
Standardised incidence ratio (SIR) & 1 & \\
Combination SIR/PIR & & \\
Mortality/incidence studies: & 1 & $61-64$ \\
SIR/MOR & 40 & \\
Number of reports & 19 & \\
Number of independent studies & & \\
Case-control and cohort studies: & 4 & \\
Case-control (C-C), incidence & & \\
Cohort: & 56 & \\
SMR & 12 & \\
PMR/MOR & 1 & \\
Nested C-C (mortality) & 12 & \\
SIR & 106 & \\
SIR/SMR & 92 & \\
PH (incidence) & 147 & \\
Number of reports & 15 & \\
Number of independent studies & & \\
Total number of reports & & \\
Total number of independent studies & & \\
\hline
\end{tabular}

*The following studies were considered to be based on the same data base: five PMR studies from British Columbia ${ }^{3032-35}$; four studies from the United Kingdom 21404445 ; three studies from the Swedish cancer registry 51525 ; four incidence studies from the Danish cancer registry $y^{48} 535456$; and 10 studies based on mortality data from the United

$\star \star$ The studies by Aronson and Howe, ${ }^{24}$ Seniori Costantini et al, ${ }^{47}$ and the Danish ${ }^{485-54} 56$ and Finnish ${ }^{55}$ studies, based on linking occupational data obtained at one point in time-for example, from census data - with subsequent cancer incidence or mortality data, were not considered as cohort studies in this report.

$\mathrm{PH}=$ proportional hazards analysis. design, although some investigations did not fit neatly into one simple category. Nineteen studies (of 40 reports) relied on routinely collected data or data collected for other administrative purposes-for example, special labour force surveys ${ }^{24}$-whereby mortality or cancer incidence statistics were calculated with or without census denominators-for example, proportional mortality (PMR) studies and standardised incidence ratio (SIR) studies, respectively. Twelve of these studies were based on mortality figures, ${ }^{21-47}$ six studies were based on incidence data, ${ }^{48-59}$ and one study combined incidence and mortality. ${ }^{60}$ There were also four incident case-control studies, ${ }^{61-64}$ and 92 investigations of cohorts (from 106 reports; table 3). ${ }^{65-170}$

\section{Results}

The studies with routinely collected data usually covered a wide variety of occupational circumstances and were from different parts of the world. ${ }^{21-25} 29$ 30 32-35 $394044-505357$ Other administrative studies, not all independent from these, were directed toward specific types of industries or occupations: agriculture, ${ }^{31} 385860$ beauticians and cosmetologists, ${ }^{59}$ electrical workers, ${ }^{424356}$ electronics industry, ${ }^{51}$ health care workers, ${ }^{27}{ }^{55}$ jewellers, ${ }^{37}$ laundry and dry cleaning, ${ }^{264154}$ pharmaceuticals, ${ }^{21}$ printing, ${ }^{52}$ shoe manufacturing, ${ }^{36}$ telephone workers, ${ }^{43}$ and textiles. ${ }^{28}$

Two of the four case-control studies were population based, ${ }^{6162}$ one was based on patients admitted to Roswell Park Memorial Institute, Buffalo, NY, ${ }^{63}$ and the fourth ${ }^{64}$ was a nested study among patients referred to a breast cancer screening clinic in New York City. In general, response rates in three of these studies were adequate ${ }^{62-64}$ and control populations were selected appropriately. The focus of the report by Franceschi et $a l^{62}$ was on farming and agricultural occupations and that of Koenig and collaborators ${ }^{64}$ was on cosmetologists. We assumed that in all of these studies there was the opportunity to investigate a wide variety of occupational circumstances.

Thirty three different occupations or industries were investigated in the cohort studies, as well as 16 different exposures to chemical agents (table 3 ). Eight occupational circumstances were studied more than twice: asbestos workers (eight independent studies); chemical and related workers (five studies); cosmetologists (four studies); pharmaceuticals (three studies); rubber industry (six studies); shoe manufacturing (four studies); textiles and garment workers (five studies); and $x$ ray technicians and radiation workers (six studies).

Excluding cohort studies that relied on PMR or mortality odds ratio (MOR) analyses, the median number of women included in these studies was about 1500: 18 studies included more than 5000 subjects, and six studies included more than 10000 subjects. ${ }^{73} 778096134135153154$ The median number of breast cancer cases was 19 (mean of 64), and only five studies had more than 100 cases. ${ }^{75} 7680134135153$ Although table 3 shows that 
Table 3 Design characteristics, occupational circumstances, and chemical exposures that were investigated in the cohort studies

\begin{tabular}{|c|c|c|c|c|c|c|c|c|c|}
\hline & $\begin{array}{l}\text { Reports } \\
n\end{array}$ & $\begin{array}{l}\text { Study } \\
\text { design }\end{array}$ & $\begin{array}{l}\text { Exposure- } \\
\text { response* }\end{array}$ & $\underset{n}{\text { Women }}$ & $\begin{array}{l}\text { Cases } \\
n\end{array}$ & $\begin{array}{l}\text { Rela } \\
\text { risk† }\end{array}$ & $\begin{array}{l}\text { tive } \\
95 \% \mathrm{CI}\end{array}$ & $\begin{array}{l}\text { Statistical } \\
\text { power(\%) }\end{array}$ & Reference \\
\hline Occupations or industries: & & & & & & & & & \\
\hline Abattoirs & 2 & SMR & $\mathbf{N}$ & 3935 & 26 & 0.7 & $(0.5-0.9)$ & 100 & 65,66 \\
\hline Actors & 1 & PMR & $\mathbf{N}$ & NA & 53 & $1 \cdot 2$ & $(0.9-1.5)$ & 100 & \\
\hline Aircraft maintenance & 1 & SMR & C & 3138 & 30 & 0.7 & $(0 \cdot 5-1 \cdot 0)$ & 100 & 68 \\
\hline Aircraft manufacturing & 1 & SMR & $\mathbf{N}$ & 950 & NR & NR. & (NC) & NC & 69 \\
\hline Artists & 1 & PMR & $\mathrm{N}$ & NA & 21 & 1.9 & $(1 \cdot 2-2 \cdot 9)$ & 87 & 70 \\
\hline Cable manufacturing & & & & & & & & & \\
\hline (chlorinated naphthalenes) & 1 & SMR & $\mathrm{L}$ & 3042 & 47 & $1 \cdot 0$ & $(0 \cdot 7-1 \cdot 3)$ & 100 & 71 \\
\hline Chemical industry, chemists & 6 & MOR & $\overline{\mathbf{N}}$ & NA & 30 & 1.6 & $(1 \cdot 1-2 \cdot 9)$ & 97 & 72 \\
\hline & & SMR & $\mathbf{Y}$ & 10839 & 54 & $1 \cdot 1$ & $(0 \cdot 8-1 \cdot 5)$ & 100 & 73 \\
\hline & & MOR & $\mathbf{N}$ & NA & 7 & $5 \cdot 3$ & $(2 \cdot 8-10 \cdot 1)$ & 25 & 74 \\
\hline & & SIR & $\mathbf{S}$ & NR & 395 & $1 \cdot 2$ & $(1 \cdot 0-1 \cdot 3)$ & 100 & 75,76 \\
\hline & & SMR & $\mathbf{S}$ & NR & 156 & 0.9 & $(0 \cdot 8-1 \cdot 0)$ & 100 & 75,76 \\
\hline & & SMR & $\mathbf{S}$ & 24461 & 39 & $1 \cdot 0$ & $(0 \cdot 7-1 \cdot 4)$ & 100 & 77 \\
\hline Cosmetologists & 4 & SMR & $\mathbf{N}$ & 7736 & 5 & 0.6 & $(0 \cdot 2-1 \cdot 4)$ & 78 & 78 \\
\hline & & SMR & $\mathbf{N}$ & 677 & 9 & 0.7 & $(0 \cdot 3-1 \cdot 3)$ & 91 & 79 \\
\hline & & SIR & $\mathbf{N}$ & 677 & 7 & 0.6 & $(0 \cdot 2-1 \cdot 2)$ & 90 & 79 \\
\hline & & SIR & $\mathbf{Y}$ & 11845 & 204 & $1.0 \$$ & $(0 \cdot 9-1 \cdot 2)$ & 100 & 80 \\
\hline & & SIR & $\mathbf{N}$ & 3637 & 70 & $1 \cdot 2$ & $(1 \cdot 0-1 \cdot 6)$ & 100 & 81 \\
\hline Dry cleaning & 4 & SMR & $\mathbf{N}$ & 1109 & 19 & $1 \cdot 0$ & $(0 \cdot 6-1 \cdot 7)$ & 97 & 82,83 \\
\hline & & SMR & E & 4046 & 36 & $1 \cdot 0$ & $(0 \cdot 7-1 \cdot 4)$ & 100 & 84,85 \\
\hline Electric light manufacturing & 1 & SIR & $\tilde{N}$ & 1044 & 21 & $1 \cdot 2$ & $(0 \cdot 8-1 \cdot 8)$ & 50 & 86 \\
\hline Foundry workers & 2 & SMR & $\mathbf{Y}$ & 627 & NR & NR & (NC) & NC & 87 \\
\hline & & SMR & Y,L & 2243 & 2 & 0.5 & $(0 \cdot 1-1 \cdot 9)$ & 49 & 88 \\
\hline Furniture manufacture & 1 & SMR & $\mathbf{N}$ & 6680 & 53 & 0.7 & $(0.5-0.9)$ & 100 & 89 \\
\hline Gardeners & 2 & SMR & $\mathrm{N}$ & 151 & NR & NR & (NC) & NC & 90 \\
\hline & & SIR & $\mathrm{N}$ & 859 & 10 & $1 \cdot 1$ & $(0 \cdot 5-2 \cdot 1)$ & 81 & 91 \\
\hline Jewellery workers & 1 & PMR & $\mathbf{N}$ & 1083 & NR & NR & (NC) & NC & 92 \\
\hline 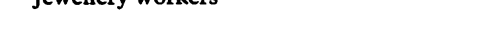 & $\mathbf{P}$ & PMR & $\mathbf{N}$ & NA & 30 & 0.8 & $(0 \cdot 5-1 \cdot 1)$ & 100 & 92 \\
\hline Laboratory workers & 1 & SMR" & $\mathbf{N}$ & 685 & 8 & $2 \cdot 9$ & $(1 \cdot 2-5 \cdot 7)$ & 40 & 93 \\
\hline Leather tanning & 1 & SMR & $\mathrm{Y}, \mathrm{L}$ & 482 & NR & NR & (NC) & NC & 94 \\
\hline & & SIR & $\bar{Y}, \bar{L}$ & 482 & 19 & 1.5 & $(0 \cdot 9-2 \cdot 3)$ & 91 & 94 \\
\hline Motor vehicle manufacturing & 2 & PMR & $\mathbf{N}$ & NA & 5 & $1 \cdot 1$ & $(0 \cdot 4-2 \cdot 5)$ & 56 & 95 \\
\hline & & SMR & $\mathrm{N}$ & 11271 & 52 & 0.7 & $(0 \cdot 5-1 \cdot 0)$ & 100 & 96 \\
\hline Municipal workers & 1 & SMR & $\mathbf{N}$ & 1199 & 10 & 0.8 & $(0 \cdot 4-1 \cdot 6)$ & 89 & 97 \\
\hline Pathologists & 1 & SMR & $\mathbf{N}$ & 803 & 4 & $1 \cdot 6$ & $(0 \cdot 4-4 \cdot 1)$ & 37 & 98 \\
\hline Petroleum manufacturing workers & 1 & SMR & $\overrightarrow{\mathrm{L}}$ & 8249 & 20 & $1 \cdot 0$ & $(0 \cdot 6-1 \cdot 5)$ & 98 & 99 \\
\hline Pharmaceuticals, pharmacy technicians & 3 & PMR & $\mathbf{N}$ & NA & 22 & $1 \cdot 8$ & $(1 \cdot 1-2 \cdot 7)$ & 90 & 100 \\
\hline & & SIR & $\mathbf{N}$ & 8499 & 70 & $1 \cdot 1$ & $(0 \cdot 8-1 \cdot 4)$ & 100 & 101 \\
\hline & & SIR & $\mathrm{L}, \mathrm{Y}$ & 5554 & 97 & $1 \cdot 5$ & $(1 \cdot 2-1 \cdot 8)$ & 100 & 102 \\
\hline Polyurethane foam manufacture & 1 & SMR & $\mathbf{Y}$ & 2465 & 11 & $0 \cdot 7$ & $(0 \cdot 3-1 \cdot 2)$ & 95 & 103 \\
\hline & & SIR & $\mathbf{Y}$ & 2465 & 23 & $1 \cdot 0$ & $(0 \cdot 6-1 \cdot 4)$ & 99 & 103 \\
\hline Pottery industry & 1 & PMR & $\mathbf{N}$ & 946 & NR & NR & (NC) & NC & 104 \\
\hline Pulp and paper, sawmills & 2 & SIR & $\mathrm{L}$ & 849 & 8 & 0.6 & $(0 \cdot 3-1 \cdot 3)$ & 90 & 105 \\
\hline & & SIR & $\overline{\mathbf{N}}$ & 502 & 8 & 0.8 & $(0 \cdot 4-1 \cdot 7)$ & 82 & 106 \\
\hline Reindeer breeders & 1 & SIR & $\mathbf{N}$ & 757 & 5 & 0.4 & $(0 \cdot 1-0 \cdot 8)$ & 92 & 107 \\
\hline Rubber and affiliated industry & 7 & SMR\| & $\mathbf{N}$ & 4200 & 56 & 0.8 & $(0 \cdot 6-1 \cdot 1)$ & 100 & 108,109 \\
\hline & & SMR\| & $\mathrm{N}$ & 3377 & 22 & 0.9 & $(0 \cdot 6-1 \cdot 4)$ & 100 & 108,109 \\
\hline & & SMR & $\mathrm{N}$ & 1649 & 5 & 0.4 & $(0 \cdot 1-1 \cdot 0)$ & 90 & 110 \\
\hline & & SMR,SIR & $\mathrm{L}$ & 4280 & NR & NR & (NC) & NC & 111 \\
\hline & & SMR & $\mathbf{N}$ & 667 & NR & NR & (NC) & NC & 112 \\
\hline & & SMR & $\mathbf{N}$ & 2492 & 6 & 0.6 & $(0 \cdot 2-1 \cdot 2)$ & 85 & 113 \\
\hline & & SIR & $\mathbf{N}$ & 2492 & 11 & 0.6 & $(0 \cdot 3-1 \cdot 0)$ & 100 & 113 \\
\hline & & SMR & $\mathbf{N}$ & 250 & NR & NR & (NC) & NC & 114 \\
\hline Semiconductor workers & 2 & SMR & $\mathbf{N}$ & 1526 & 7 & 0.5 & $(0 \cdot 2-1 \cdot 1)$ & 91 & 115,116 \\
\hline & & SIR & $\mathrm{N}$ & 1526 & 20 & 0.8 & $(0 \cdot 5-1 \cdot 1)$ & 100 & 115,116 \\
\hline Shoe manufacturing & 4 & PMR & $\mathbf{N}$ & NA & 81 & $1 \cdot 0$ & $(0 \cdot 8-1 \cdot 2)$ & 100 & 117 \\
\hline & & PMR & $\mathbf{N}$ & NA & 52 & $1 \cdot 1$ & $(0 \cdot 8-1 \cdot 4)$ & 100 & 118 \\
\hline & & SMR & $\mathbf{L}$ & 1005 & & 0.9 & $(0 \cdot 2-2 \cdot 3)$ & 55 & 119 \\
\hline & & SMR & $\mathrm{L}$ & 5285 & NR & NR & (NC) & NC & 120 \\
\hline Synthetic vitreous mineral fibre industry ${ }^{\star \star}$ & 3 & SMR & $\mathbf{Y}$ & 4380 & 11 & 0.8 & $(0 \cdot 4-1 \cdot 3)$ & 94 & 121 \\
\hline & & SIRHt & $\mathrm{Y}, \mathrm{L}$ & 3214 & 16 & $0 \cdot 8$ & $(0 \cdot 4-1 \cdot 3)$ & 98 & 122 \\
\hline & & SMR & Y,L & NR & NR & NR & (NC) & NC & 123 \\
\hline Telecommunications workers & 2 & SMR & $\mathbf{N}$ & 867 & 7 & 0.6 & $(0 \cdot 3-1 \cdot 3)$ & 86 & 124 \\
\hline & & SMR & $\mathbf{N}$ & 2398 & 5 & 0.9 & $(0 \cdot 3-2 \cdot 0)$ & 62 & 125 \\
\hline Textiles and garments & 6 & SMR & $\mathbf{N}$ & 923 & & NR & (NC) & NC & 126 \\
\hline & & SMR & $\mathbf{N}$ & 725 & NR & NR & (NC) & NC & 127 \\
\hline & & PMR & $\mathbf{N}$ & NA & NR & NR & (NC) & NC & 128 \\
\hline & & SMR & $\mathrm{Y}, \mathrm{L}$ & 9022 & 33 & 0.7 & $(0 \cdot 5-1 \cdot 0)$ & 100 & 129,130 \\
\hline & & SMR & $\mathrm{L}$ & 2724 & 33 & $1 \cdot 2$ & $(0 \cdot 8-1 \cdot 6)$ & 100 & 131 \\
\hline Waitresses and bartenders & 1 & SIR & $\mathbf{Y}$ & 5314 & 83 & 0.8 & $(0 \cdot 6-1 \cdot 0)$ & 100 & 132 \\
\hline$x$ Ray technicians, radiation workers & 8 & SMR & $\mathrm{C}$ & 594 & NR & NR & (NC) & NC & 133 \\
\hline & & SIR & $\mathrm{C}$ & 594 & 1 & 0.3 & $(0 \cdot 0-1 \cdot 5)$ & 49 & 133 \\
\hline & & SMRtt & $\mathrm{C}$ & 3366 & 21 & 0.7 & $(0 \cdot 4-1 \cdot 0)$ & 100 & 134,135 \\
\hline & & SMRff & $\mathbf{N}$ & 15086 & 157 & $1 \cdot 0$ & $(0.9-1 \cdot 2)$ & 100 & 134,135 \\
\hline & & SMRt & C & 2598 & 4 & 1.0 & $(0 \cdot 3-2 \cdot 6)$ & 50 & 136 \\
\hline & & SMR & $\mathbf{N}$ & 2598 & 10 & 0.7 & $(0 \cdot 3-1 \cdot 2)$ & 98 & 136 \\
\hline & & SMR & $\mathbf{N}$ & 677 & 5 & 0.5 & $(0 \cdot 2-1 \cdot 2)$ & 84 & 137 \\
\hline & & SIR & L & 5443 & 11 & 1.4 & $(0.7-2.4)$ & 76 & 138 \\
\hline & & SIRtt & $\mathbf{N}$ & NR & 3 & 2.5 & $(0.6-6.8)$ & 23 & 139 \\
\hline & & cInt & & $\mathrm{NR}$ & 19 & 0.9 & $(0.5-1.3)$ & 98 & 130 \\
\hline & & SIRł‡ & & NR & & 0.9 & $(0 \cdot 5-1 \cdot 3)$ & 98 & 139 \\
\hline & & SMF & $\rightarrow D, C$ & 8473 & NR & NR & (NC) & NC & 140 \\
\hline
\end{tabular}

Table 3 continued overleaf

statistical power was above $80 \%$ in about $75 \%$ of studies, the small number of cases found indicates that the power to detect excess risks in subgroups and to test for trends in exposure was generally low.

A variety of indices of exposure or surrogates of exposure were used in these studies, but in only 10 studies 68102131 134-136 155 166-168 were risks of breast cancer actually presented by level or duration of exposure.
PRINCIPAL FINDINGS

Table 4 shows the number of studies with at least one significant positive association for female breast cancer as well as the number of studies with the potential for investigating each occupational circumstance. This denominator was calculated from a baseline of 16 studies (four case-control studies ${ }^{61-64}$ and 12 other independent studies based on administrative data) and, for specific occupational cir- 
Table 3 continued

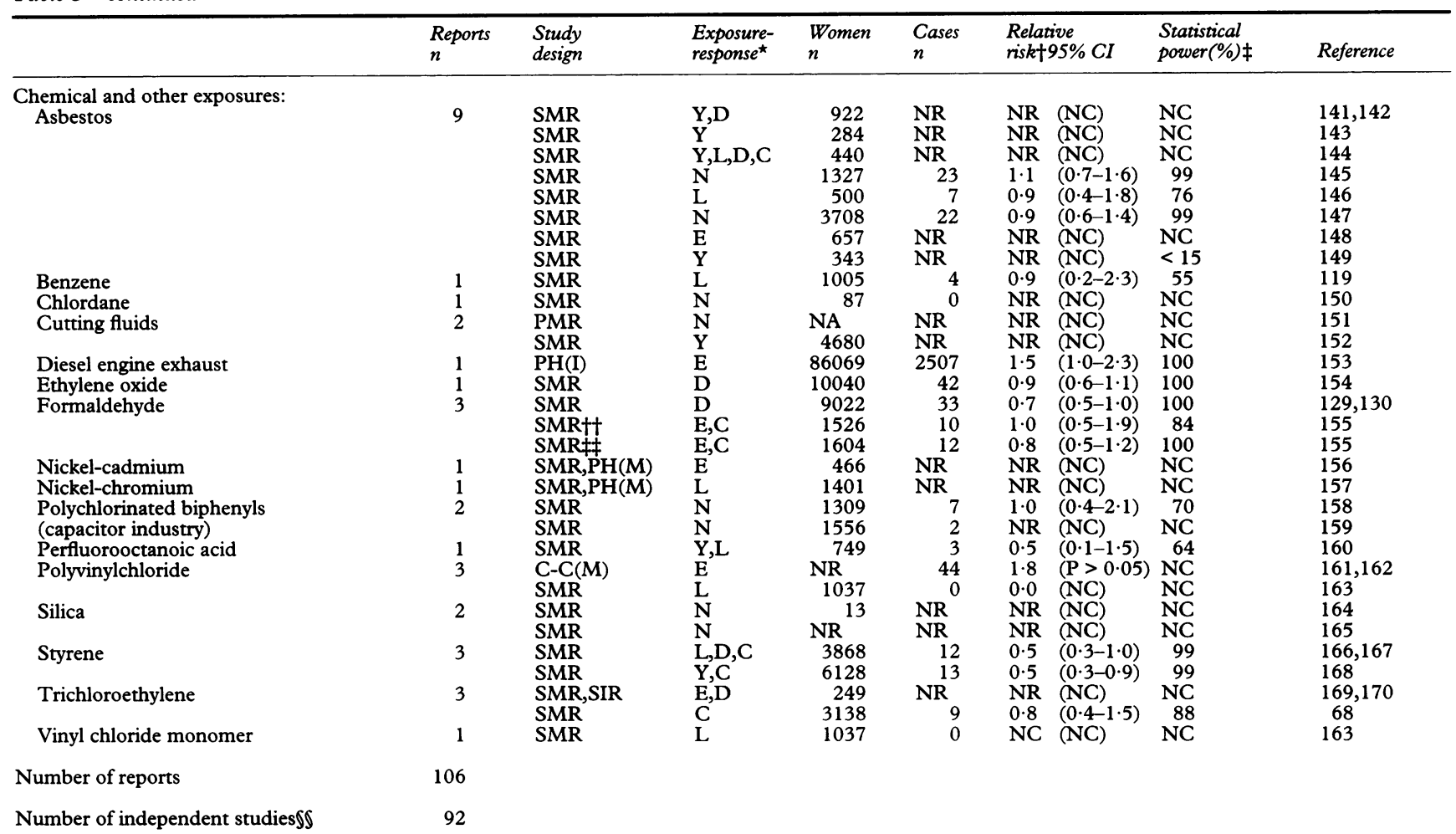

All but one of the cohort studies were based on industrial populations; this one ${ }^{153}$ included subscribers to a health insurance plan.

$\mathrm{NA}=$ not applicable; $\mathrm{NC}=$ not calculable; $\mathrm{NR}=$ not reported; $\mathrm{C}-\mathrm{C}(\mathrm{M})=$ nested mortality case-control study; $\mathrm{PH}(\mathrm{I} / \mathrm{M})=$ proportional hazards analysis of incidence (I) or mortality (M)

^Exposure-response represents the type of analyses considered by the authors of the report. However, such analyses were not necessarily reported for breast cancer. Abbreviations: $N=$ none; $L=$ length of employment; $\mathrm{Y}=$ year since first hire; $\mathrm{S}=$ salary/wage; $\mathrm{E}=$ level of exposure; $\mathrm{D}=$ duration of exposure; and $\mathrm{C}=$ cumulative exposure.

†Relative risks refer to the whole population, unless otherwise stated. For a series of reports, estimates are quoted for the latest publication.

$¥$ Statistical power to detect a relative risk of 2 (5\% level of significance) was calculated with the method of Beaumont and Breslow ${ }^{171}$. The expected number of cases for values of power are: $50 \%: 3 \cdot 93$ expected cases; $80 \%: 8 \cdot 98 ; 90 \%: 12 \cdot 44 ;$ and $95 \%: 15 \cdot 72$.

for values of power are: $50 \%: 3.93$ expected cases; $80 \%: 8 \cdot 98 ; 90 \%: 12 \cdot 44 ;$ and $95 \%: 15 \cdot 72$.

\&An excess risk was found among women who started work before 1935 (SMR $=1 \cdot 27 ; 95 \%$ CI: $1 \cdot 01-1 \cdot 57)$.
qFirst line represents data for a cohort of union members (PMR analysis), and the second line represents a PMR analysis based on death certificates.

IFirst line represents data for a cohort of union members (PMR analysis), and
$\|$ First line is for wage (union) employees and second line for salary employees.

$\star \star$ The studies in the synthetic vitreous mineral fibre by Saracci and colleagues ${ }^{121}$ and Simonato et al ${ }^{122}$ included 13 European plants.

††Refers to exposed or monitored workers.

$\neq$ Refers to unexposed or unmonitored workers.

ISNon-independent studies were: United Kingdom radiation workers, ${ }^{134-136}$ Hanford workers, ${ }^{139} 140$ and workers in the synthetic vitreous mineral fibre industry. ${ }^{121} 122$

cumstances, it was augmented from among other studies in which there was the possibility that these circumstances could have been investigated. These denominators should be considered to be approximate because information on the composition of the workforce, and consequently the types of occupational circumstances that could be investigated, were not usually described. In what follows, we will clarify some of the main points in table 4 and describe the more interesting results.

\section{Clerical and professional}

Associations with cancer incidence or mortality with clerical and professional jobs were reported primarily in studies based on administrative data. These studies were from widely different areas of the world, including Canada, ${ }^{24} 3335$ China, ${ }^{57}$ Denmark, ${ }^{48}{ }^{53}$ Finland, ${ }^{55}$ Holland, ${ }^{25}$ Italy, ${ }^{47}$ Japan, ${ }^{49}$ Russia, ${ }^{23}$ the United Kingdom, ${ }^{40} 4445$ and the United States. 222746 The number of studies showing excess risks was rather striking for several occupational categories: white collar, professional and managerial occupations; $22-2427294044-4648495357$ clerical, secretarial, and related jobs; 22232729333540434648495357 teachers; $2223272933354044-4853$ nurses; 222325272933354655 scientists; 2223272933354693 physicians and other health professionals; 222327293335404446485355 and clergy. 222527294649

In one case-control study, ${ }^{61}$ excess risks were found for clerical workers, for people employed in the insurance industry, but significant negative associations were also reported for people working in professional and related services, and managers and administrators. In seven cohort studies involving industrial popu-

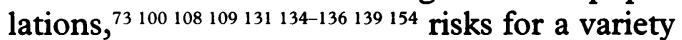
of administrative and secretarial or clerical occupations were not greater than expected. Also, a study of municipal workers ${ }^{97}$ did not show any associations for any job category, including clerks, professional, and technical.

In view of the fact that exposures to specific occupational agents cannot be identified easily in most of these occupational groups, one must inquire whether methodological weaknesses, such as uncontrolled confounding, in the administrative studies produced spurious results. In particular, the effect of confounding was examined in only one PMR study. ${ }^{32} 35$ Here it was found that PMRs for teachers and nurses were reduced when homemakers were removed from the control group (teachers: PMR 1.68 ( $P<0.05)$ and $1.37(P<0.05)$; nurses: PMR 1.20 $(\mathrm{P}<0.05)$ and 0.99 , 
Table 4 Summary of the evidence linking selected occupational circumstances with breast cancer in women

\begin{tabular}{|c|c|c|c|c|c|}
\hline \multirow[b]{2}{*}{ Occupational circumstance } & \multicolumn{4}{|c|}{$\begin{array}{l}\text { Number of studies with at least } \\
\text { one positive significant finding }\end{array}$} & \multirow{2}{*}{$\begin{array}{l}\text { Total number of } \\
\text { studies with the } \\
\text { possibility of } \\
\text { investigating the } \\
\text { circumstance }\end{array}$} \\
\hline & $\begin{array}{l}\text { Admin- } \\
\text { istrative }\end{array}$ & Cohort & $\begin{array}{l}\text { Case- } \\
\text { control }\end{array}$ & Total & \\
\hline \\
\hline Clerical and related jobs & 9 & 0 & 1 & $12 \dagger$ & 22 \\
\hline Teachers & 7 & 0 & 0 & ${ }_{7}^{10}$ & $\begin{array}{l}22 \\
16\end{array}$ \\
\hline Scientists & 7 & 1 & 0 & 8 & 17 \\
\hline Nurses & 7 & 0 & 0 & 7 & 17 \\
\hline Other health professionals & 4 & 1 & 0 & 5 & 18 \\
\hline Clergy & 3 & 0 & 0 & 3 & 16 \\
\hline Cosmetologists, beauticians & 2 & 2 & 1 & 5 & 21 \\
\hline Pharmaceutical industry & 1 & 2 & 0 & 3 & 19 \\
\hline Food industry & 2 & 0 & 0 & $2 \ddagger$ & 17 \\
\hline Textile and clothing workers & 2 & 0 & 0 & $2 \coprod^{+}$ & 22 \\
\hline Bartenders and waitresses & 1 & 0 & 0 & 19 & 17 \\
\hline 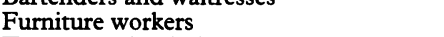 & 0 & 1 & 0 & $1 \|$ & 17 \\
\hline Transportation industry & 1 & 0 & 0 & $1^{\star \star}$ & 16 \\
\hline Electronics manufacturing & 1 & 0 & 0 & i & 17 \\
\hline Printing & 1 & 0 & 0 & 1 & 17 \\
\hline Farmers, agriculture & 1 & 0 & 0 & $1 \mathrm{tt}$ & 19 \\
\hline Shoe and leather & 0 & 1 & 0 & 1 & 21 \\
\hline$x$ Ray technicians, radiation workers & 0 & 1 & 0 & 1 & 21 \\
\hline Laundry and dry cleaning & 0 & 0 & 0 & 0 & 18 \\
\hline Rubber workers & 0 & 0 & 0 & 0 & 22 \\
\hline \multirow{4}{*}{$\begin{array}{l}\text { Chemical industry (excluding } \\
\text { petroleum manufacturing) } \\
\text { Potential exposure to extremely low } \\
\text { frequency electromagnetic fields }\end{array}$} & 0 & 0 & 0 & 0 & 24 \\
\hline & & & & 4 & NE \\
\hline & 1 & 3 & 0 & 4 & $\mathrm{NE}$ \\
\hline & 4 & 0 & 0 & 4 & $\mathrm{NE}$ \\
\hline
\end{tabular}

Abbreviations (see also table 2): NE = not estimable.

*The baseline number of studies (16) includes: 12 studies based on administrative data $21-2729,3032-3537-3940-4648-5053-57$ and four casecontrol studies. ${ }^{61-64}$ The case-control study by Franceschi $e t a^{62}$ focused on farmers and that of Koenig and coworkers ${ }^{64}$ on beauticians. The number of studies above 16 are from the 92 independent cohort studies and the following studies based on administrative data: electronics, ${ }^{51}$ printing, ${ }^{52}$ farmers and agricultural occupations, ${ }^{315860}$ textiles, ${ }^{28}$ shoe and leather manufacturing, ${ }^{36}$ health tive data: electronics, ${ }^{51}$ printing, ${ }^{52}$ farmers and agriculture workers, ${ }^{55}$ and beauticians and cosmetologists. ${ }^{59}$

†Relative risks from one case-control study (professional and related services) ${ }^{61}$ and one PMR study (domestics) ${ }^{33}$ were signifi†Relative risks from one
cantly less than expected.

cantly less than expected.
†Exludes bartenders, waitresses, and workers in hotels and restaurants. One SIR study ${ }^{48}$ and one SMR/PMR study significant deficits.

Significant negative associations were found in one PMR study, ${ }^{28}$ in three SIR studies, ${ }^{47-49}$ in one case-control study, ${ }^{63}$ and in one cohort study of garment workers exposed to formaldehyde. ${ }^{129130}$

qFour studies showed significant deficits. ${ }^{29} 333439132$

|The positive association was from one cohort study, and it was restricted to black women working with wood furniture ${ }^{89}$; a significant negative association was found for white women working in all furniture industries combined.

${ }_{\star \star A}$ A significant negative association was found in one SIR study. ${ }^{48}$

H+Significant negative associations were found in two SIR studies, ${ }^{49}$ in one PMR study among non-white women, ${ }^{38}$ family workers in Denmark and farm employees in Italy, ${ }^{60}$ and in a SIR study of Swedish reindeer herders. ${ }^{58}$

respectively), ${ }^{35}$ thus suggesting that some or all of the excess risk may be due to confounding by reproductive factors. Nevertheless, health professionals are of considerable interest because they may be exposed to a wide variety of agents, including anaesthetic gases and organic solvents. ${ }^{172}$ In the one major longitudinal study of nurses, risks of breast cancer relative to the general population have not been reported. ${ }^{173}$ Lastly, a cohort study of scientists, laboratory technicians, and maintenance workers showed a significant increase in the risk of breast cancer (table 3).$^{93}$ Exposures were diverse, including radiation, solvents, chemical mutagens, and viruses.

Cosmetologists, hairdressers, and beauticians Of the four cohort studies ${ }^{78-81}$ investigating cosmetologists, two studies ${ }^{8081}$ showed increased risks of about $20 \%$ (table 3). The negative results may be due to low statistical power. ${ }^{78} 79$ In the case-control study of Koenig et $a l,{ }^{64}$ a relative risk of 3.0 (95\% CI $\left.1 \cdot 1-7 \cdot 8\right)$ was found among beauticians employed for five or more years. Significantly increased relative risks were detected in three administrative studies: $R R \quad 1.6 \quad(P<0.05),{ }^{22} \quad R R \quad 1.3$ $(\mathrm{P}<0.05),{ }^{49}$ and RR $1.2(95 \%$ CI $0 \cdot 9-1 \cdot 6) .{ }^{53}$ It is likely that cosmetologists have been exposed to several potentially toxic agents, such as organic dusts (hair), hair dyes, organic solvents (in nail products, settings, lotions, and hair sprays), and detergents. There is little information on the carcinogenicity of most of these substances, although some organic solvents are accepted animal and human carcinogens (benzene); hair dyes do not seem to be associated with a risk of breast cancer. ${ }^{64}$

\section{Pharmaceutical industry}

Positive associations were found in two cohort studies of pharmaceutical workers (table 3). ${ }^{100} 102$ There was a suggestion that incidence rates increased by duration of service among workers involved in the manufacture of insulin, sex hormones, and other pharmaceutical products. ${ }^{102}$ Confounding by reproductive factors may not be an important issue in this study, as current plant personnel and the general population were shown to have similar distributions of number of children, age of mother at first birth, age at menarche, and body mass index. However, a significantly higher frequency of oral contraceptive use, a weak risk factor for breast cancer, and a slightly higher use of noncontraceptive sex hormones were found among workers. No associations were found in the investigation of pharmacy technicians ${ }^{101}$ and in the case-control studies, and one study based on administrative data showed an excess risk among black women working in the pharmaceutical industry (RR 1.6, P $<0.05) .{ }^{50}$ The discrepant findings in the studies of pharmacy technicians and pharmaceutical manufactur- 
Table 5 Relative risks of female breast cancer in relation to occupations with potential exposure to extremely low frequency electromagnetic fields

\begin{tabular}{|c|c|c|c|c|}
\hline $\begin{array}{l}\text { Type of study } \\
\text { based on } \\
\text { administrative data }\end{array}$ & Reference & Occupation or industry & Relative risk & $\begin{array}{l}95 \% \mathrm{CI} \\
\text { or P value }\end{array}$ \\
\hline SMR & 22 & White women, telephone operators & $1 \cdot 7$ & $P<0.05$ \\
\hline SMR & 23 & Communication & $2 \cdot 9$ & $1 \cdot 7-4 \cdot 6$ \\
\hline PMR & 40 & Telephone operators & $1 \cdot 3$ & $P<0.05$ \\
\hline MOR & $42^{\star}$ & $\begin{array}{l}\text { Electrical engineers } \\
\text { Electrical technicians } \\
\text { Telephone installers, repairers, line } \\
\text { workers } \\
\text { Other "electrical occupations" }\end{array}$ & $\begin{array}{l}1 \cdot 7 \\
1 \cdot 3 \\
2 \cdot 2 \\
0 \cdot 7\end{array}$ & $\begin{array}{l}0 \cdot 9-3 \cdot 3 \\
0 \cdot 8-2 \cdot 1 \\
1 \cdot 2-4 \cdot 0 \\
0 \cdot 4-1 \cdot 3\end{array}$ \\
\hline MOR & $43^{\star}$ & $\begin{array}{l}\text { Telephone industry } \\
\text { White women } \\
\text { Black women } \\
\text { Black and white women combined } \\
\text { Office workers } \\
\text { Telephone operators } \\
\text { Engineers and technicians } \\
\text { Mechanics and repairers }\end{array}$ & $\begin{array}{l}1 \cdot 4 \\
2 \cdot 2 \\
\\
2 \cdot 5 \\
0 \cdot 9 \\
2 \cdot 7 \\
1 \cdot 6\end{array}$ & $\begin{array}{l}1 \cdot 3-1 \cdot 5 \\
1 \cdot 6-3 \cdot 1 \\
1 \cdot 8-3 \cdot 5 \\
0 \cdot 5-1 \cdot 6 \\
1 \cdot 3-6 \cdot 0 \\
0 \cdot 8-3 \cdot 2\end{array}$ \\
\hline SMR & 51 & Telecommunications industry & $0 \cdot 6$ & $0 \cdot 3-1 \cdot 3$ \\
\hline SIR & 56 & $\begin{array}{l}\text { Exposure to intermittent magnetic field }(>0.3 \mu \mathrm{T}) \\
\text { Exposure to continuous magnetic field }(>0.3 \mu \mathrm{T})\end{array}$ & $\begin{array}{l}1 \cdot 0 \\
0 \cdot 9\end{array}$ & $\begin{array}{l}0 \cdot 9-1 \cdot 0 \\
0 \cdot 7-1 \cdot 2\end{array}$ \\
\hline
\end{tabular}

In tables 5 and 6 , relative risks for all cohort studies are presented, as well as those studies based on administrative data in which excess relative risks (lower confidence limit $\geqslant 0.9$ ) were found. When CIs were not presented but observed and expected numbers were available, $95 \%$ CIs were calculated by us assuming a Poisson distribution. Otherwise the original $\mathrm{P}$ values are shown.

$\star$ References 42 and 43 were based on the same data.

ing workers are most simply explained by the fact that technicians are not likely to be exposed to the same extent as manufacturing workers.

\section{Textiles and clothing}

No associations were found in the two small cotton textile manufacturing cohort studies, ${ }^{126} 127$ among textile workers, dyers and bleachers, ${ }^{128}$ and among workers manufacturing synthetic fibres and textiles (mostly cellulose acetate) ${ }^{131}$ (table 3 ). There were no associations with formaldehyde exposure in the study of garment workers. ${ }^{129130}$ In one case-control study, significant deficits were found among workers in the textile mill industry, ${ }^{63}$ and no associations were reported in the other case-control studies. ${ }^{616264}$ Two studies based on regularly collected data showed excess risks, ${ }^{44} 45$ and significant deficits were found in four other studies. ${ }^{2847-49}$

Radiation workers and $x$ ray film technicians Six cohort studies have been conducted among radiation workers, including diagnostic $x$ ray film personnel, ${ }^{138}$ workers at a uranium fuel fabrication plant, ${ }^{133}$ a thorium processing plant, ${ }^{137}$ United Kingdom Atomic Energy Authority plants, ${ }^{134} 135$ the Sellafield reprocessing plant, ${ }^{136}$ and the Hanford site in Washington state 139140 (table 3). Exposures across the studies were quite varied, including whole body ionising radiation as well as exposure to radionuclides. Despite the fact that ionising radiation is a recognised risk factor for breast cancer, ${ }^{5}$ none of these studies showed any excess risks.

Potential exposure to extremely low frequency electromagnetic fields

In 1987 , Stevens ${ }^{174}$ suggested that breast cancer may be caused by exposure to extremely low frequency electromagnetic fields. It was suggested that these fields would reduce pineal melatonin production, thereby allowing levels of oestrogen and prolactin to increase. Thus, extremely low frequency electromagnetic fields indirectly may affect hormonal secretions thereby increasing the risk of breast cancer. This hypothesis has stimulated much debate, but few epidemiological studies have been carried out among women. Four studies of male breast cancer ${ }^{175-178}$ have shown associations with employment in "electrical occupations". The only reports on female breast cancer derive from six administrative studies 2234042435156 of which four have shown associations with a variety of electrical occupations 22234042 (table 5)

\section{Chemists and chemical workers}

Higher than expected risks among chemists were found in MOR analyses of two cohorts, ${ }^{72} 74$ with considerably higher risks noted in single women (MOR 2.3, 95\% CI 1.5-3.5). ${ }^{72}$ For chemical manufacturing workers, higher than expected incidence rates of breast cancer were found among Du Pont company workers ${ }^{75} 76$; there were higher risks among salaried workers (SMR 1.3) than among those paid on an hourly basis (SMR 0.9). No associations were found among Dow Chemical ${ }^{73}$ or Union Carbide workers. ${ }^{77} \mathrm{~A}$ difficulty in interpreting these studies is that workers were most likely exposed at various levels to a wide array of chemical agents. It is therefore unclear how to interpret the findings between salaried staff and hourly wage earners. One PIR study ${ }^{50}$ showed increased risks among black women working in the chemical industry ( $R R 1.4$; $P<0.05$ ), and no positive associations with general chemical occupations were reported in the case-control studies

Other specific chemical exposures have been investigated (table 3 ), with negative results reported for women exposed to chlori- 
Table 6 Relative risks of female breast cancer in relation to occupations with potential exposure to organic solvents

\begin{tabular}{|c|c|c|c|c|}
\hline $\begin{array}{l}\text { Type of } \\
\text { study }\end{array}$ & Reference & Occupation, industry, or exposure & Relative risk & $\begin{array}{l}95 \% \mathrm{CI} \\
\text { or P value }\end{array}$ \\
\hline \multirow[t]{4}{*}{ Cohort } & 68 & $\begin{array}{l}\text { Aircraft maintenance workers } \\
\text { Exposed to trichloroethylene } \\
\text { (no trend for cumulative exposure) }\end{array}$ & $\begin{array}{l}0 \cdot 7 \\
0 \cdot 8\end{array}$ & $\begin{array}{l}0.5-1 \cdot 0 \\
0.4-1 \cdot 5\end{array}$ \\
\hline & & Exposed to freon & $3 \cdot 1$ & $1 \cdot 2-6 \cdot 4$ \\
\hline & & Exposed to solder flux & $3 \cdot 1$ & $1 \cdot 1-6 \cdot 7$ \\
\hline & & Exposed to isopropyl alcohol & & $1 \cdot 3-6 \cdot 4$ \\
\hline \multirow[t]{2}{*}{ Cohort } & 82,83 & $\begin{array}{l}\text { Dry cleaners } \\
\text { Entire cohort }\end{array}$ & $1 \cdot 1$ & $0 \cdot 6-1 \cdot 7$ \\
\hline & & $\begin{array}{l}\text { Perchloroethylene only subcohort } \\
\text { Perchloroethylene and other exposures }\end{array}$ & $\begin{array}{l}1 \cdot 0 \\
1 \cdot 1\end{array}$ & $\begin{array}{l}0.4-2.2 \\
0.6-1.9\end{array}$ \\
\hline \multirow[t]{2}{*}{ Cohort } & $\begin{array}{l}84,85 \\
86\end{array}$ & $\begin{array}{l}\text { Dry cleaners } \\
\text { Lamp manufacturing (coiling/wire drawing) }\end{array}$ & 1.0 & $0 \cdot 7-1 \cdot 4$ \\
\hline & & $\begin{array}{l}>6 \text { months employment } \\
\text { (Possible exposure to methylene chloride } \\
\text { and trichloroethylene.) }\end{array}$ & $2 \cdot 0$ & $0 \cdot 9-4 \cdot 0$ \\
\hline \multirow[t]{2}{*}{ Cohort } & 94 & $\begin{array}{l}\text { Leather tannery workers } \\
\text { Incidence }\end{array}$ & & \\
\hline & & $\begin{array}{l}\text { No latency period } \\
\geqslant 20 \text { years latency }\end{array}$ & $\begin{array}{l}1.3 \\
1.5\end{array}$ & $0 \cdot 8-2 \cdot 0$ \\
\hline Cohort & 119 & $\begin{array}{l}\text { Shoe manufacturing } \\
\text { (Exposure to benzene and other solvents.) }\end{array}$ & 0.9 & $0 \cdot 2-2 \cdot 3$ \\
\hline Cohort & 120 & $\begin{array}{l}\text { Shoe manufacturing } \\
\text { (Exposure to toluene and other solvents.) }\end{array}$ & NR & . \\
\hline $\begin{array}{l}\text { Cohort } \\
\text { Cohort* } \\
\text { Cohort } \\
\text { Cohort } \\
\text { Cohort } \\
\text { C-C }\end{array}$ & $\begin{array}{c}129,130 \\
161,162 \\
166,167 \\
168 \\
169,170 \\
61\end{array}$ & $\begin{array}{l}\text { Garment workers exposed to formaldehyde } \\
\text { Polyvinylchloride workers } \\
\text { Styrene exposed workers } \\
\text { Styrene exposed workers } \\
\text { Trichloroethylene exposed workers } \\
\text { Miscellaneous manufacturing industry } \\
\text { Operators in fabricated metal } \\
\text { Operators in printing and publishing } \\
\text { Operators in leather industry }\end{array}$ & $\begin{array}{l}0 \cdot 7 \\
1 \cdot 8 \\
0 \cdot 5 \\
0.5 \\
\text { NR } \\
0 \cdot 6 \\
0 \cdot 5 \\
0 \cdot 4 \\
1 \cdot 2\end{array}$ & $\begin{array}{l}0.5-1.0 \\
P>0.05 \\
0.3-1.0 \\
0.3-0.9 \\
P<0.01 \\
P=0.04 \\
P=0.03 \\
P>0.05\end{array}$ \\
\hline \multicolumn{5}{|c|}{ Studies based on administrative data: } \\
\hline $\begin{array}{l}\text { SMR } \\
\text { SMR }(<50) \dagger\end{array}$ & $\begin{array}{l}24 \\
45\end{array}$ & $\begin{array}{l}\text { Printing and publishing } \\
\text { All others in painting, repetitive } \\
\text { assembling, product inspection, }\end{array}$ & $2 \cdot 2$ & $1 \cdot 1-3 \cdot 9$ \\
\hline $\operatorname{PMR}(\geqslant 60) \dagger$ & 45 & $\begin{array}{l}\text { packaging and related } \\
\text { All others in painting, repetitive } \\
\text { assembling, product inspection, }\end{array}$ & 1.5 & $0 \cdot 9-2 \cdot 2$ \\
\hline $\begin{array}{l}\text { MOR } \\
\text { PMR } \\
\text { MOR } \\
\text { PMR } \\
\text { PIR } \\
\text { SIR }\end{array}$ & $\begin{array}{l}50 \\
53\end{array}$ & $\begin{array}{l}\text { packaging and related } \\
\text { WW, mechanics and repairers } \\
\text { WW, precision production } \\
\text { WW, precision production } \\
\text { BW, precision production } \\
\text { BW, printing industry } \\
\text { Bookbinder's assistant } \\
\text { Self employed/iron-metal industry } \\
\text { Self employed/photographic studios }\end{array}$ & $\begin{array}{l}1 \cdot 4 \\
1 \cdot 7 \\
1 \cdot 0 \\
1 \cdot 1 \\
1 \cdot 2 \\
1 \cdot 8 \\
1 \cdot 5 \\
2 \cdot 9 \\
2 \cdot 3\end{array}$ & $\begin{array}{l}0 \cdot 9-2 \cdot 0 \\
1 \cdot 2-2 \cdot 4 \\
P>0.05 \\
1 \cdot 0-1 \cdot 2 \\
P<0.05 \\
P<\delta \cdot 05 \\
0.9-2 \cdot 3 \\
1 \cdot 0-6 \cdot 8 \\
0.6-6.0\end{array}$ \\
\hline
\end{tabular}

$\mathrm{WW}=$ White women; $\mathrm{BW}=$ black women. See previous tables for other abbreviations.

*Case-control analysis of the cohort.

$\dagger$ Numbers in parentheses represent ages of subjects. Married women were excluded from consideration.

nated naphthalenes in the cable manufacturing industry, ${ }^{71}$ workers exposed to ethylene oxide, ${ }^{154}$ and rubber manufacturing workers. ${ }^{108-110113}$ A positive association was found among women potentially exposed to diesel engine exhaust. ${ }^{153}$

\section{Potential exposure to organic solvents}

We have hypothesised (Labrèche and Goldberg, submitted for publication) ${ }^{179}$ that exposure to organic solvents may be associated with an increased risk of breast cancer. The suggested mechanism is through migration of these lipophilic substances, and their metabolites, to adipose tissue in the breast where they can be stored, absorbed into the apocrine glands, possibly biotransformed, and then excreted into the ductal systems where they may remain in contact with the parenchyma for considerable amounts of time, thereby initiating or promoting carcinogenesis. There are experimental data that suggest that some organic solvents are carcinogenic in rats and mice (benzene, 1,2-dibromoethane, 1,1dichloroethane, 1,2-dichloroethane, methylene chloride (benign tumours), styrene, 1,2,3trichloropropane, and vinyl chloride). ${ }^{180} 181$

Table 6 shows that the epidemiological data are rather sparse. Of interest are workers in laundry and dry cleaning establishments who have been exposed to several organic solvents. Stoddard solvent was used until the 1930s, after which carbon tetrachloride becane the mainstay. ${ }^{82} 85$ Perchloroethylene slowly replaced the earlier solvents between the 1940s and the 1960s. Trichloroethylene and, more recently, fluorocarbons have been used. According to Brown and Kaplan, ${ }^{82}$ by 1977 , $74 \%$ of the industry used perchloroethylene, $24 \%$ used petroleum based solvents, and about $2 \%$ used fluorocarbons. No increased risks of breast cancer were noted among workers exposed to perchloroethylene, ${ }^{8283}$ or to a mixture of solvents, including Stoddard solvent, perchloroethylene, trichloroethylene, and fluorocarbons. ${ }^{85}$ None of the case-control studies nor those studies based on administrative data showed any increased risks.

The mortality study by Spirtas et al ${ }^{68}$ of aircraft maintenance workers exposed to trichloroethylene was consistent with the null results from the studies of dry cleaners. Excess risks were found, however, for exposure to freons, solder flux, and isopropyl alcohol. These substances were highly correlated and it was not possible to disentangle individual effects. Axelson and coworkers ${ }^{169} 170$ also investigated cancer incidence and mortality in workers 
exposed to trichloroethylene. No risk estimates were provided for cancer of the breast, and one must assume that very few cases were found. Incidence of breast cancer was in excess among women employed in coiling and wire drawing ${ }^{86}$ in the manufacturing of lamps, in which methylene chloride and trichloroethylene were probably used.

Two cohort studies of female shoe manufacturers have been carried out. ${ }^{119} 120$ Exposures included organic solvents and solvent based adhesives; in the study by Paci et al ${ }^{119}$ benzene was originally an important component of glues used before the mid-1960s (up to $70 \%$ by weight) and may have been an impurity in the investigation by Walker and colleagues. ${ }^{120}$ Other solvents used typically were toluene, hexane, methyl ethyl ketone, and acetone in concentrations ranging from $10 \mathrm{ppm}$ to $330 \mathrm{ppm} .{ }^{120}$ The small study by Paci et al ${ }^{119}$ showed no increased risks, and in the larger American study ${ }^{120}$ risk estimates were not reported for cancer of the breast.

Mikoczy and coworkers conducted a cohort study of leather tannery workers exposed to several compounds, ${ }^{94}$ including benzene and other chlorinated solvents, and found incidence rates to be between $30 \%$ and $50 \%$ above those expected. A case-control study in a small cohort of polyvinyl chloride workers showed a non-significantly increased risk of death from breast cancer (OR 1·8). ${ }^{161} 162$ No associations were found among workers exposed to styrene. ${ }^{166-168}$ Lastly, among the studies based on administrative records, there have been suggestions of increased risks for certain occupations that may involve exposures to solvents (printing, publishing, mechanics)..$^{245465053}$

\section{Discussion and conclusions}

This review has summarised results from occupational investigations of female breast cancer carried out within the past 25 years. Our perspective on investigations based on routinely collected data is that they may convey spurious conclusions if used by themselves, although they can be used for generating hypotheses or providing additional information to that obtained from cohort and case-control studies. The reason for treating the administrative studies in this way is their inherent limitations, ${ }^{33182183}$ including: (1) misclassification of disease status leading to reductions in statistical power and attenuation of risk ratios. Mortality data are more susceptible to these types of problems than incidence data. ${ }^{184-187}$ Moreover, because of the relatively long survival rates for breast cancer, statistical power would be further reduced in mortality studies because of an underascertainment of cases. (2) Misclassification of exposure through the use of coarse occupational categories will also lead to a loss of statistical power and an attenuation of risk ratios. ${ }^{188}$ In the studies we reviewed, exposure was usually classified in terms of the last occupation (or industry) that the subject had had, or the occupation of the longest duration. This can also lead to bias, possibly away from the null, if workers changed occupations because of illness. Notable exceptions were the Chinese study by Zheng and coworkers, ${ }^{57}$ in which occupational histories were obtained directly from subjects (although denominators were based on census data), and the longitudinal studies from Canada, ${ }^{24}$ Italy, ${ }^{47}$ Denmark, ${ }^{48} 5356$ Sweden, ${ }^{51} 5258$ and Finland ${ }^{55}$ in which occupations from censuses or labour surveys ${ }^{24}$ were linked with subsequent cancer incidence or mortality data. (These were not considered as cohort studies in this report because personyears of observation by occupation at the time of enumeration were not calculable.) (3) Inability to account for key confounding factors may lead to incorrect inferences. Important risk factors for breast cancer were not accounted for in any of the investigations based on administrative data. That incorrect conclusions may be drawn from administrative studies is exemplified by the observation that although increased risks of developing breast cancer for clerical and white collar jobs were found in studies using administrative data, no associations were found in the cohort or casecontrol studies. It is possible that the studies of exposure to extremely low frequency electromagnetic fields, also based on routinely collected data, were biased. ${ }^{183}$ (4) No estimates of risk by duration of employment, latency, or other indices of exposure-response were presented, thus making it difficult to assess the veracity of the associations.

Thus, we relied whenever possible on information from cohort and case-control studies, that we considered to be more robust. Nevertheless, because few studies were designed specifically to investigate risks of breast cancer, the limitations inherent in these studies must be recognised when interpreting the data. In particular, statistical power and risk estimates would have been reduced in mortality studies in which broad occupational groups were used as surrogates for exposure. As well, statistical power was generally quite low for assessing trends or for assessing risks in subgroups.

Also, confounding by reproductive factors may have affected some of the cohort studies. For example, in the studies of chemists and chemical workers higher risks were found among clerical workers ${ }^{73}$ and among salaried workers $^{75-77}$ than among hourly paid workers. On the other hand, no great differences for a variety of risk factors were found between workers and the general population in the one cohort study in which confounding was assessed indirectly. ${ }^{102}$

It has been suggested that removing homemakers from reference populations will partly control for the confounding influence of reproductive and related factors. ${ }^{32} 35$ This has been applied to studies based on administrative data, but could also be implemented in casecontrol studies in which confounding variables are not measured. In the analyses of cohort studies that used mortality rates derived from the general population as the reference, homemakers can also be eliminated if occupational 
information has been captured on death certificates.

One would expect in cohort studies that misclassification of exposure would be less pronounced than in studies with routinely collected data because job titles from plants should be more homogeneous for exposure. Nevertheless, exposures were ascertained in but a handful of studies. In the case-control studies, although detailed information on occupational lifetime histories was obtained directly from subjects, broad occupational groupings were reported in the analyses, with main lifetime occupation used in two studies, ${ }^{6162}$ ever employed or employed for more than five years used in another study, ${ }^{63}$ and duration of employment reported in one study. ${ }^{64}$ In this last study, ${ }^{64}$ important confounding variables for risk of breast cancer were accounted for.

Selection into and out of work among subjects enrolled in cohort studies (the healthy worker effect ${ }^{189}$ ) may also have led to underestimation of risks. It is difficult to control for these effects, although partial control of selection into the cohort can be achieved through the use of internal control groups. However, no studies reported such analyses for breast cancer, although they were carried out for other endpoints in several studies. ${ }^{131} 133-136139153156157163168$

Bearing in mind these limitations, we conclude that there is little support for an association between female breast " cancer and employment in the textile and garment industries. The studies of cosmetologists and beauticians and of pharmaceutical manufacturing workers can be regarded as providing limited evidence in favour of an association, but further studies are required before conclusions can be drawn. Although nuclear workers are exposed to ionising radiation, a recognised risk factor for breast cancer, no associations were found. In the absence of bias, it is likely that either the length of follow up or the doses incurred were not sufficiently high to induce any observable excess risks.

There are insufficient data to make any inferences about women employed as chemists or exposed occupationally to extremely low frequency electromagnetic fields. Because of the apparent heterogeneity of exposures among workers included in the cohort studies at the large chemical companies, ${ }^{73} 75-77$ it is difficult to draw any conclusions from these studies. However, the few studies carried out on specific occupational agents have not provided any evidence of associations. In particular, although we have postulated that exposure to organic solvents may increase the risk of developing breast cancer, with some evidence provided from animal carcinogenicity studies, increased risks have not been found among dry cleaning workers, those exposed to trichloroethylene, or shoe manufacturers. Studies of organic solvents may, however, be beset with health related differential selection into and out of work arising from pervasive early onset toxic effects (dermatitis, hepatic and renal toxicity, central nervous system depression, peripheral neuropathy).${ }^{190}$ Thus, there will be a selection bias if susceptible or sensitive workers are at higher risk of developing breast cancer and are more likely to leave exposed jobs early so they are less highly exposed than insensitive people. In any event, as few organic solvents have been studied adequately, including the agents already mentioned, no conclusions on the relation between organic solvents and risk of female breast cancer can be made.

It is clear from this review that few high quality studies directed specifically toward assessing occupational risks of breast cancer have been carried out to allow one to identify unambiguously occupational risk factors for breast cancer. The fact that the cohorts of women were generally small is understandable, as few women would have been in the workforce during the period covered by many of these retrospective studies. It is now feasible to carry out more detailed investigations. Juxtaposing job exposure matrices to already completed cohort or case-control studies ${ }^{191}$ will provide a cost effective method to study occupational exposures. Also, population based, case-control studies, with approaches similar to those developed by Siemiatycki et al, Gérin et al, and Stewart et al, ${ }^{182 ~ 192-194}$ although more expensive, should provide high quality data to investigate occupational risk factors. In fact, we are now carrying out such an investigation in Montreal. Cohort studies of specific industrial populations can then be carried out to follow up promising leads from the casecontrol studies.

1 Campbell MK, Feuer EJ, Wun L-M. Cohort-specific risks of developing breast cancer to age 85 in Connecticut. Epidemiology 1994;5:290-6.

2 National Cancer Institute of Canada. Canadian cancer statistics 1994. Toronto: National Cancer Institute of Canada, 1994.

3 Kelsey JL, Gammon MD, John EM. Reproductive factors and breast cancer. Epidemiol Rev 1993;15:36-47.

4 Pike MC, Spicer DV, Dahmoush L, Press MF. Estrogens, progestogens, normal breast cell proliferation
breast cancer risk. Epidemiol Rev 1993;15:17-35.

5 Committee on the Biological effects of Ionizing Radiation, National Research Council. Health effects of exposure to low levels of ionizing radiation. Washington, DC: US
National Academy Press, 1990 .

6 Rosenberg L, Metzger LS, Palmer JR. Alcohol consumption and risk of breast cancer: a review of the epidemiologic evidence. Epidemiol Rev 1993;15:133-44

7 Davis DL, Bradlow HL, Wolff M, Woodruff T, Hoel DG, Anton-Culver H. Medical hypothesis: xenoestrogens as preventable causes of breast cancer. Environ Health Perspect 1993;101:372-7.

8 Miller AB. Dietary fat and the epidemiology of breast cancer. In: Ip C, Birt DF, Rogers AE, Mettlin C, eds. Dietary fat and cancer. New York: Alan R Liss, 1986. 9 Hunter DJ, Willett WC. Diet, body size, and breast can-

10 MacMahon B. Pesticide residues and breast cancer? $\mathcal{f}$ Natl Cancer Inst 1994;86:572-3.

11 Wigle DT. Breast cancer and fertility trends in Canada. Am $\mathcal{f}$ Epidemiol 1977;105:428-38.

12 Stevens RG, Moolgavkar SH, Lee JAH. Temporal trends in breast cancer. Am ₹ Epidemiol 1982;115:759-77.

13 Holford TR, Roush GC, McKay LA. Trends in female breast cancer in Connecticut and the United States. f Clin Epidemiol 1991;44:29-39.

14 Feuer EJ, Wun L-M. How much of the recent rise in breast cancer incidence can be explained by increases in mammography utilization? A dynamic population model approach. Am f Epidemiol 1992;136:1423-36.

15 Doll R, Peto R. The causes of cancer. $\mathcal{F}$ Natl Cancer Inst 1981;66:1197-312.

16 Kelsey JL. Breast cancer epidemiology: summary and future directions. Epidemiol Rev 1993;15:256-63.

17 Statistics Canada. Women in Canada: a statistical report. 2nd ed. Ottawa, Canada: Ministry of Supply and 2nd ed. Ottawa, Canada: Ministry of Supply and 89-503E.) 
18 Pottern LM, Hoar Zahm S, Sieber SS, Schneider IJ, LaRosa JH, Brown DP, et al. Occupational cance among women: a conference overview. $\mathcal{f}$ Occup Med 1994;36:809-13.

19 Hoar Zahm S, Pottern LM, Lewis DR, Ward MH Selected bibliography: occupational cancer epidemiology studies presenting data on women. Distributed at the "International Conference on Women's Health: Occupation and Cancer", Baltimore, MD: 1993.

20 Hoar Zahm S, Pottern LM, Lewis DR, Ward MH, White DW. Inclusion of women and minorities in occupational cancer epidemiologic research. $¥$ Occup Med 1994;36: 842-7.

21 Harrington JM, Goldblatt P. Census based mortality study of pharmaceutical industry workers. $\mathrm{Br} \mathcal{f}$ Ind $\mathrm{Med}$ 1986;43:206-11.

22 Doebbert G, Riedmiller KR, Kizer KW. Occupational mortality of California women, 1979-81. West $\mathcal{f}$ Med 1988;149:734-40.

23 Bulbulyan M, Zahm SH, Zaridze DG. Occupational cancer mortality among urban women in the former USSR. Cancer Causes Control 1992:3:299-307.

24 Aronson KJ, Howe GR. Utility of a surveillance system to detect associations between work and cancer among women in Canada, 1965-91. F Occup Med 1994;36: 1174-9.

25 Versluys JJ. Cancer and occupation in the Netherlands. $\mathrm{Br}$ f Cancer 1949;3:161-85

26 Katz RM, Jowett D. Female laundry and dry cleaning workers in Wisconsin: a mortality analysis. $A m \mathcal{F}$ Public Health 1981;71:305-7.

27 Katz RM. Causes of death among registered nurses. 7 Occup Med 1983;25:760-2.

28 Delzell E, Grufferman S. Cancer and other causes of death among female textile workers 1976-8. I Natl death among female textile

29 Milham S Jr. Occupational mortality in Washington State 1950-79. Cincinnati, OH: US Department of Health and Human Services, Centres for Diseases Control, National Institute for Occupational Safety and Health 1983. (DHHS NIOSH Publication No 83-116.)

30 Spinelli J, Gallagher RP, Band PR, Threlfall WJ. Multiple myeloma, leukemia, and cancer of the ovary in cosmetologists and hairdressers. Am $\mathcal{F}$ Ind Med 1984; 6:97-102.

31 Stubbs HA, Harris J, Spear RC. A proportionate mortality analysis of California agricultural workers, 1978-9. $A m$ f Ind Med 1984;6:305-20.

32 Threlfall WJ, Gallagher RP, Spinelli JJ, Band PR. Reproductive variables as possible confounders in occupational studies of breast and ovarian cancer in females. pational studies of breast and

33 Gallagher RP, Threlfall WJ, Band PR, Spinelli J, Coldman AJ. Occupational mortality in British Columbi 1950-78. Ottawa, Canada: Statistics Canada, 1986. (Statistics Canada Publication 84-544.)

34 Dimich-Ward H, Gallagher RP, Spinelli J, Threlfall WJ, Band PR. Occupational mortality among bartenders and waiters. Can $\mathcal{F}$ Public Health 1988;79:194-7.

35 King AS, Threlfall WJ, Band PR, Gallagher RP. Mortality among female registered nurses and school teachers in
British Columbia. Am $\mathcal{F}$ Ind Med 1994;26:125-32.

36 Garabrant DH, Wegman DH. Cancer mortality among shoe and leather workers in Massachusetts. Am $\mathcal{F}$ Ind Med 1984;5:303-14.

37 Dubrow R, Gute DM. Cause-specific mortality among Rhode Island jewelry workers. Am F Ind Med 1987;12: 579-93.

38 Blair A, Dosemeci M, Heineman EF. Cancer and other causes of death among male and female farmers from twenty-three states. Am f Ind Med 1993;23:729-42.

39 Burnett CA, Dosemeci M. Using occupational mortality data for surveillance of work-related diseases of women. f Occup Med 1994;36:1199-203.

40 Roman E, Beral V, Inskip H. Occupational mortality among women in England and Wales. $B M F$ 1985;291:

41 Duh RW, Asal NR. Mortality among laundry and dry cleaning workers in Oklahoma. Am f Public Health 1984; 74:1278-80.

42 Loomis DP, Savitz DA, Ananth CV. Breast cancer mortality among female electrical workers in the United States. F Natl Cancer Inst 1994;86:921-5.

43 Dosemeci M, Blair A. Occupational cancer mortality among women employed in the telephone industry. $\mathcal{F}$ Occup Med 1994;36:1204-9.

44 Registrar General of Great Britain. Occupational mortality: the Registrar-General's decennial supplement for England and Wales, 1970-72. London, England: Her Majesty's Stationary Office, 1978 .

45 Registrar General of Great Britain. Occupational mortality decennial supplement, 1979-80, 1982-83. Part 1 commentary. London, England: Her Majesty's Stationery Office, 1986 .

46 Rubin $\mathrm{CH}$, Burnett CA, Halperin WE, Seligman PJ. Occupation as a risk identifier for breast cancer. $A m$ F Public Health 1993;83:1311-5.

47 Seniori Costantini A, Pirastu R, Lagorio S, Miligi L Costa G. Studying cancer among female workers: methods and preliminary results from a record-linkage system in Italy. $\mathcal{F}$ Occup Med 1994;36:1180-6.

48 Olsen JH, Jensen OM. Occupation and risk of cancer in Denmark. An analysis of 93810 cancer cases, 1970-9. Scand f Work Environ Health 1987;13(suppl 1):91. 49 Kato I, Tominaga S, Ikari A. An epidemiological study on 20:121-7.
50 Hall NEL, Rosenman KD. Cancer by industry: analysis of a population-based cancer registry with an emphasis on blue-collar workers. Am F Ind Med 1991;19:145-59.

51 Vágerö $D$, Olin $R$. Incidence of cancer in the electronics industry: using the new Swedish Cancer Environment Registry as a screening instrument. $\mathrm{Br} \mathcal{F}$ Ind Med 1983;40:188-92.

52 Malker HSR, Gemne G. A register-epidemiology study on cancer among Swedish printing industry workers. Arch Environ Health 1987;42:73-82.

53 Lynge E, Thygesen L. Occupational cancer in Denmark. Cancer incidence in the 1970 census population. Scand 7 Work Environ Health 1990;16(suppl 2):7-35.

54 Lynge E, Thygesen L. Primary liver cancer among women in laundry and dry-cleaning work in Denmark. Scand $\mathcal{F}$ Work Environ Health 1990;16:108-12.

55 Sankila R, Karjalainen S, Läärä E, Pukkala E, Teppo L Cancer risk among health care personnel in Finland,

6 Guenel $P$. Scand $f$ Work Environ Health 1990;16:252-7. Incidence of cancer in persons with occupational exposure to electromagnetic fields in Denmark. Br f Ind Med 1993;50:758-64.

57 Zheng W, Shu XO, McLaughlin JK, Chow WH, Gao YT, Blot WJ. Occupational physical activity and the incidence of cancer of the breast, corpus uteri, and ovary in Shanghai. Cancer 1993;71:3620-4.

58 Wiklund $\mathrm{K}$, Dich J. Cancer risks among female farmers in Sweden. Cancer Causes Control 1994;5:449-57.

59 Menck HR, Pike MC, Henderson BE, Jing JS. Lung cancer risk among beauticians and other female workers: brief communication. $\mathcal{F}$ Natl Cancer Inst 1977;59:1423-5.

60 Ronco G, Costa G, Lynge E. Cancer risk among Danish and Italian farmers. Br $₹$ Ind Med 1992;49:220-5.

61 Williams RR, Stegens NL, Goldsmith JR. Associations of cancer site and type with occupation and industry from cancer site and type with occupation and industry from the third National Cancer

62 Franceschi S, Barbone F, Bidoli E, Guarneri S, Serraino $D$, Talamini $R$, La Vecchia C. Cancer risk in farmers: results from a multi-site case-control study in northeastern Italy. Int $\mathcal{f}$ Cancer 1993;53:740-5.

63 Decoufé P, Stanislawczyk K, Houten L, Bross IDJ, Viadana E. $A$ retrospective survey of cancer in relation to occupation. Cincinnati, $\mathrm{OH}$ : National Institute for Occupational Safety and Health, 1977. (NIOSH publication 77-178.)

64 Koenig KL, Pasternack BS, Shore RE, Strax P. Hair dye use and breast cancer: a case-control study among 985-95.

65 Johnson ES, Fischman HR, Matanoski GM, Diamond E. Occurrence of cancer in women in the meat industry. $\mathrm{Br}$ F Ind Med 1986;43:597-604.

66 Johnson ES. Cancer mortality among workers in the meat department of supermarkets. Occup Environ Med 1994 51:541-7.

67 Depue RH, Kagey BT, Heid MF. A proportional mortality study of the acting profession. Am F Ind Med 1985; 8:57-66.

68 Spirtas R, Stewart PA, Lee JS, Marano DE, Forbes CD, Grauman DJ. Retrospective cohort mortality study Epidemiological results. $\mathrm{Br} \mathcal{F}$ Ind Med 1991;48: 515-30.

69 Costa G, Merletti F, Segnan N. A mortality cohort study in a north Italian aircraft factory. $\mathrm{Br} \mathcal{F}$ Ind $\mathrm{Med} 1989 ; 46$ 738-43.

70 Miller BA, Blair A, McCann M. Mortality patterns among professional artists: a preliminary report. $f$ Environ Pathol 1985;6:303-13.

71 Ward EM, Ruder AM, Suruda A, Smith AB, Halperin W, Fessler CA, Hoar Zahm S. Cancer mortality patterns among female and male workers employed in a cable manufacturing plant during World War II. f Occup Med manufacturing plan

72 Walrath J, Li FP, Hoar SK, Mead MW, Fraumeni JF. Causes of death among female chemists. Am $\mathcal{Y}$ Public Health 1985;75:883-5.

73 Bond GG, McLaren EA, Cartmill JB, Wymer KT, Lipps TE, Cook RR. Mortality among female employees 563-78.

74 Dosemeci M, Alavanja M, Vetter R, Eaton B, Blair A. Mortality among laboratory workers employed at the US Department of Agriculture Epidemiology 1992;3:258-62.

75 Pell S, O'Berg MT, Karrh BW. Cancer epidemiologic surveillance in the Du Pont Company. $f$ Occup Med 1978;20:725-40.

76 O'Berg MT, Burke CA, Chen JL, Walrath J, Pell S, Gallie $\mathrm{CR}$. Cancer incidence and mortality in the Du Pont Company: an update. $f$ Occup Med 1987;29:245-52.

77 Teta MJ, Schnatter AR, Ott MG, Pell S. Mortality surveillance in a large chemical company: the Union Carbide Corporation experience, 1974-83. Am $\mathcal{F}$ Ind Med 1990;17:435-47.

78 Kono S, Tokudome S, Ikeda M, Yoshimura T, Kuratsune $M$. Cancer and other causes of death among female beauticians. $\mathcal{f}$ Natl Cancer Inst 1983;70:443-6.

79 Gubéran E, Raymond L, Sweetnam PM. Increased risk for male bladder cancer among a cohort of male and female hairdressers from Geneva. Int $\mathcal{f}$ Epidemiol 1985;14: 549-54.

80 Teta MJ, Walrath J, Meigs JW, Flannery JT. Cancer incidence among cosmetologists. F Natl Cancer Inst 1984; 72:1051-7. 
81 Pukkala E, Nokso-Koivisto P, Roponen P. Changing cancer risk pattern among Finnish hairdressers. Int Arch Occup Environ Health 1992;64:39-42.

82 Brown DP, Kaplan SD. Retrospective cohort mortality study of dry cleaner workers using perchloroethylene. $f$ Occup Med 1987;29:535-40.

83 Ruder AM, Ward EM, Brown DP. Cancer mortality in female and male dry-cleaning workers. $f$ Occup Med 1994;36:867-74.

84 Blair A, Decoufle P, Grauman D. Causes of death among laundry and dry cleaning workers. Am $\mathcal{f}$ Public Health 1979;69:508-11.

85 Blair A, Stewart PA, Tolbert PE, Grauman D, Moran FX, Vaught J, Rayner J. Cancer and other causes of death among a cohort of dry cleaners. Br $\mathcal{F}$ Ind Med death among a

86 Shannon HS, Haines T, Bernholz C, Julian JA, Verma DK, Jamieson E, Walsh C. Cancer morbidity in lamp manufacturing workers. Am $\mathcal{F}$ Ind Med 1988;14:281-90.

87 Andjelkovich DA, Mathew RM, Richardson RB, Levine RJ. Mortality of iron foundry workers: I. Overall findings. F Occup Med 1990;32:529-40.

88 Rotimi C, Austin H, Delzell E, Day C, Macaluso M, Honda Y. Retrospective follow-up study of foundry and engine plant workers. Am $\mathcal{f}$ Ind Med 1993;24:485-98.

89 Miller BA, Blair A, Reed EJ. Extended mortality followup among men and women in a US furniture workers up among men and women in a US furt

90 Littorin M, Attewell R, Skerfving S, Horstmann V, Möller T. Mortality and tumour morbidity among Swedish market gardeners and orchardists. Int Arch Occup Environ Health 1993;65:163-9.

91 Hansen ES, Hasle H, Lander F. A cohort study on cancer incidence among Danish gardeners. Am $\mathcal{F}$ Ind $\mathrm{Med}$ 1992;21:651-60.

92 Hayes RB, Dosemeci M, Riscigno M, Blair A. Cancer mortality among jewelry workers. $\mathrm{Am} \mathcal{f}$ Ind $\mathrm{Med}$ 1993;24:743-51.

93 Belli S, Comba P, De Santis M, Grignoli M, Sasco AJ Mortality study of workers by the Italian National Institute of Health,

94 Mikoczy Z, Schütz A, Hagmar L. Cancer incidence and mortality among Swedish leather tanners. Occup Environ Med 1994;51:530-5.

95 Silverstein M, Mirer F, Kotelchuck D, Silverstein B, Bennett M. Mortality among workers in a die-casting and electroplating plant. Scand $\mathcal{F}$ Work Environ Health 1981;7(suppl 4):156-65.

96 Delzell E, Beall C, Macaluso M. Cancer mortality among women employed in motor vehicle manufacturing. Occup Med 1994;36:1251-9.

97 Vena JE, Cookfair DL, Fiedler RC, Barnes RE. Mortality of a municipal worker cohort: II. Females. Am $\mathcal{f}$ Ind Med 1986;9:159-69.

98 Hall A, Harrington JM, Aw TC. Mortality study of British pathologists. Am F Ind Med 1991;20:83-9.

99 Schnatter R, Thériault G, Katz AM, Thompson FS, Donaleski D, Murray N. A retrospective mortality study within operating segments of a petroleum company. $A m$ f Ind Med 1992;22:209-29.

100 Thomas TL, Decoufle P. Mortality among workers employed in the pharmaceutical industry: a preliminary investigation. $₹$ Occup Med 1979;21:619-23.

101 Hansen J, Olsen JH. Cancer morbidity among Danish female pharmacy technicians. Scand $\mathcal{f}$ Work Environ Health 1994;20:22-6.

102 Hansen J, Olsen JH, Larsen AI. Cancer morbidity among employees in a Danish pharmaceutical plant. Int $\mathscr{f}$ Epidemiol 1994;23:891-8.

103 Sorahan T, Pope D. Mortality and cancer morbidity of production workers in the United Kingdom flexible polyurethane foam industry. $\mathrm{Br} \mathcal{F}$ Ind Med 1993;50: 528-36.

104 Thomas TL. A preliminary investigation of mortality among workers in the pottery industry. Int $\mathcal{f}$ Epidemiol among workers in

105 Jäppinen P, Hakulinen T, Pukkala E, Tola S, Kurppa K. Cancer incidence of workers in the Finnish pulp and paper industry. Scand $\mathcal{F}$ Work Environ Health 1987; 13:197-202.

106 Jäppinen P, Pukkala E, Tola S. Cancer incidence of workers in a Finnish sawmill. Scand $\mathcal{f}$ Work Environ Health 1989;15:18-23.

107 Wiklund K, Holm L-E, Eklund G. Cancer risks in Swedish Lapps who breed reindeer. Am 7 Epidemiol 1990;132:1078-82.

108 Monson RR, Nakano KK. Mortality among rubber workers. II. Other employees. Am $\mathcal{F}$ Epidemiol 1976;103: 297-303.

109 Delzell E, Monson RR. Mortality among rubber workers. III. Cause-specific mortality, 1940-78. F Occup Med 1981;23:677-84.

110 Andjelkovich D, Taulbee J, Blum S. Mortality of female workers in a rubber manufacturing plant. $\mathcal{F}$ Occup Med 1978;20:409-13.

111 Gustavsson P, Hogstedt C, Holmberg B. Mortality and incidence of cancer among Swedish rubber workers, 1952-81. Scand $\mathcal{f}$ Work Environ Health 1986;12 $538-44$

112 Zhang Z-F, Yu S-Z, Li W-X, Choi BCK. Smoking, occupational exposure to rubber, and lung cancer. $\mathrm{Br} \mathcal{F}$ Ind Med 1989;46:12-5.

113 Solionova LG, Smulevich VB. Mortality and cancer inci- dence in a cohort of rubber workers in Moscow. Scand $\mathcal{f}$ Work Environ Health 1993;19:96-101.

114 Sorahan T, Pope D. Mortality study of workers employed at a plant manufacturing chemicals for the rubber industry: 1955-86. Br f Ind Med 1993;50:998-1002.

115 Sorahan T, Waterhouse JAH, McKiernan MJ, Aston RHR. Cancer incidence and cancer mortality in a cohor of semiconductor workers. $\mathrm{Br} f$ Ind Med 1985;42. 546-50.

116 Sorahan T, Pope DJ, McKiernan MJ. Cancer incidence and cancer mortality in a cohort of semiconductor workers: an update. $B r \mathcal{F}$ Ind Med 1992;49:215-6.

117 Decouflé $P$, Walrath J. Proportionate mortality among US shoeworkers, 1966-77. Am f Ind Med 1983;4:523-32.

118 Walrath J, Decouflé P, Thomas TL. Mortality among workers in a shoe manufacturing company. $A m \mathcal{F}$ Ind Med 1987;12:615-23.

119 Paci E, Buiatti E, Seniori Costantini A, Miligi L, Pucci N, Scarpelli A. Aplastic anemia, leukemia and other cancer mortality in a cohort of shoe workers exposed to benzene. Scand f Work Environ Health 1989;15:313-8.

120 Walker JT, Bloom TF, Stern FB, Okun AH, Fingerhut MA, Halperin WE. Mortality of workers employed in shoe manufacturing. Scand $\mathcal{F}$ Work Environ Health 1993; 19:89-95.

121 Saracci $R$, Simonato $L$, Acheson ED, Andersen $A$ Bertazzi PA, Claude J. Mortality and incidence of cancer of workers in the man made vitreous fibres producing industry: an international investigation at 13 European industry: an international investigation
plants. $B r \mathcal{F}$ Ind Med $1984 ; 41: 425-36$.

122 Simonato L, Fletcher AC, Cherrie J, Andersen A, Bertazz PA, Charnay N. The man-made mineral fibre European historical cohort study. Extension of the follow-up.

123 Shannon HS, Jamieson E, Julian JA, Muir DCF. Mortality of glass filament (textile) workers. $\mathrm{Br} \mathcal{F}$ Ind Med 1990;47:533-6.

124 Vågerö D, Ahlbom A, Olin $R$, Sahlsten S. Cancer morbidity among workers in the telecommunications industry. Br $\mathcal{F}$ Ind Med 1985; $42: 191-5$.

125 DeGuire L, Cyr D, Thériault G, Provencher S, Iturra $H$, Case BW. Malignant melanoma of the skin among workers in a telecommunications industry: a mortality study. $B r \mathcal{F}$ Ind Med 1992;49:728-31.

126 Berry G, Molyneux MKB. A mortality study of workers in Lancashire cotton mills. Chest 1981;79:11S-15S.

127 Merchant JA, Ortmeyer C. Mortality of employees of two cotton mills in North Carolina. Chest 1981;79:6S-11S

128 Kirby P. Death in the textile industry: a proportional mortality study of 952 dyers, bleachers and textile workers who died between 1976 and 1980. London, England: Transport between 1976 and 1980. London, England: Transport

129 Stayner L, Smith AB, Reeve G, Blade L, Elliott L, Keenlyside $R$, Halperin W. Proportionate mortality study of workers in the garment industry exposed to study of workers in the garment industry expc
formaldehyde. $A m \mathcal{F}$ Ind Med 1985;7:229-40.

130 Stayner LT, Elliott L, Blade L, Keenlyside R, Halperin W. A retrospective cohort mortality study of worker exposed to formaldehyde in the garment industry. $\mathrm{Am} F$ Ind Med 1988;13:667-81.

131 Goldberg MS, Thériault G. Retrospective cohort study of workers of a synthetic textiles plant in Quebec: I General mortality. Am $\mathcal{f}$ Ind Med 1994;25:889-907.

132 Kjaerheim K, Andersen A. Cancer incidence among waitresses in Norway. Cancer Causes Control 1994;5:31-7.

133 Hadjimichael OC, Ostfeld AM, D'Atri DA, Brubaker RE. Mortality and cancer incidence experience of employees in a nuclear fuels fabrication plant. $F$ Occup Med 1983; 25:48-61.

134 Beral V, Inskip $H$, Fraser $P$, Booth $M$, Coleman D, Rose G. Mortality of employees of the United Kingdom Atomic Energy Authority, 1946-79. BMf 1985;291: 440-7.

135 Carpenter L, Higgins C, Douglas A, Fraser P, Beral V, Smith P. Combined analysis of mortality in three United Kingdom nuclear industry workforces, 1946-88. Radiat Res 1994;138:224-38.

136 Smith PG, Douglas AJ. Mortality of workers at the Sellafield plant of British Nuclear Fuels. $B M \mathcal{F} 1986 ; 293$ : 845-54.

137 Liu Z, Lee T-S, Kotek TJ. Mortality among workers in a thorium-processing plant-a second follow-up. Scand $\mathcal{f}$ Work Environ Health 1992;18:162-8.

138 Wang JX, Boice JD, Li BX, Zhang JY, Fraumeni JF. Cancer among medical diagnostic $x$ ray workers in China. $\mathcal{f}$ Natl Cancer Inst 1988;80:344-50.

139 Vaughan TL, Lee JAH, Strader CH. Breast cancer incidence at a nuclear facility: demonstration of a morbidity dence at a nuclear faclity: demonstration of a morbince system. Health Phys 1993;64:349-54.

140 Kneale GW, Stewart AM. Reanalysis of Hanford data: 1944-86 deaths. Am ₹ Ind Med 1993;23:371-89.

141 Newhouse ML, Berry G, Wagner JC, Turok ME. A study of the mortality of female asbestos workers. $\mathrm{Br} \mathcal{F}$ Ind Med 1972;29:134-41.

142 Newhouse ML, Berry G, Wagner JC. Mortality of factory workers in East London 1933-80. Br F Ind Med 1985, 42:4-11

143 Peto J, Doll R, Howard SV, Kinlen LJ, Lewinson HC. A mortality study among workers in an English asbestos factory. Br f Ind Med 1977;34:169-73.

144 McDonald JC, Liddell FDK, Gibbs GW, Eyssen GE, McDonald AD. Dust exposure and mortality in chrysotile mining, 1910-75. Br F Ind Med 1980;37: 11-24. 
145 Acheson ED, Gardner MJ, Pippard EC, Grime LP Mortality of two groups of women who manufactured gas masks from chrysotile and crocidolite asbestos: a 40 year follow up. $B r \mathcal{F}$ Ind Med 1982;39:344-8.

146 Wignall BK, Fox AJ. Mortality of female gas mask assemblers. Br f Ind Med 1982;39:34-8.

147 Berry G, Newhouse ML. Mortality of workers manufacturing friction materials using asbestos. $\mathrm{Br} \mathcal{f}$ Ind $\mathrm{Med}$ 1983;40:1-7.

148 Gardner MJ, Winter PD, Pannett B, Powell CA. Follow up study of workers manufacturing chrysotile asbestos cement products. Br f Ind Med 1986;43:726-32.

149 Finkelstein MM. Mortality rates among employees potentially exposed to chrysotile asbestos at two automotive
parts factories. Can Med Assoc $₹$ 1989;141:125-30.

150 Shindell S, Ulrich S. Mortality of workers employed in the manufacture of chlordane: an update. $\mathcal{F}$ Occup Med 1986;28:497-501.

151 Park RM, Wegman DH, Silverstein MA, Maizlish NA, Mirer FE. Causes of death among workers in a bearing manufacturing plant. Am $\mathcal{F}$ Ind Med 1988;13:569-80.

152 Eisen EA, Tolbert PE, Monson RR, Smith TJ. Mortality studies of machining fluid exposure in the automobile industry. I: A standardized mortality ratio analysis. $A m \mathcal{F}$ Ind Med 1992;22:809-24.

153 Van Den Eeden SK, Friedman GD. Exposure to engine exhaust and risk of subsequent cancer. 7 Occup Med exhaust and risk

154 Steenland K, Stayner L, Greife A, Halperin W, Hayes R, Hornung $R$, Newlin S. Mortality among workers exposed to ethylene oxide. $N$ Engl f Med 1991;324 1402-7.

155 Blair A, Stewart P, O'Berg M, Gaffey W, Walrath J, Ward $\mathrm{J}$, et al. Mortality among industrial workers exposed to formaldehyde. F Natl Cancer Inst 1986;76:1071-84.

156 Sorahan T, Waterhouse JAH. Mortality study of nickelcadmium battery workers by the method of regression cadmium battery workers by the method of regress
models in life tables. $B r f$ Ind Med 1983;40:293-300.

157 Sorahan T, Burges DCL, Waterhouse JAH. A mortality study of nickel/chromium platers. Br $\mathcal{F}$ Ind Med 1987 44:250-8.

158 Brown DP, Jones $M$. Mortality and industrial hygiene study of workers exposed to polychlorinated biphenyls. Arch Environ Health 1981;36:120-9.

159 Bertazzi PA, Riboldi L, Pesatori A, Radice L, Zocchetti C. Cancer mortality of capacitor manufacturing workers. Am F Ind Med 1987;11:165-76.

160 Gilliland FD, Mandel JS. Mortality among employees of a perfluorooctanoic acid production plant. $\mathcal{f}$ Occup Med 1993;35:950-4.

161 Chiazze L, Nichols WE, Wong O. Mortality among employees of PVC fabricators. F Occup Med 1977;19: employe 8 .

162 Chiazze L, Wong O, Nichols WE, Ference LD. Breast cancer mortality among PVC fabricators. f Occup Med 1980;22:677-9.

163 Smulevich VB, Fedotova IV, Filatova VS. Increasing evidence of the rise of cancer in workers exposed to vinylchloride. $B r$ f Ind Med 1988;45:93-7.

164 Finkelstein M, Liss GM, Krammer F, Kusiak RA. Mortality among workers receiving compensation awards for silicosis in Ontario 1940-85. Br $¥$ Ind Med 1987;44:588-94.

165 Katsnelson BA, Mokronosova KA. Non-fibrous mineral dusts and malignant tumors. F Occup Med 1979;21: 15-20.

166 Wong $\mathrm{O}$. A cohort mortality study and a case-contro study of workers potentially exposed to styrene in the reinforced plastics and composites industry. $\mathrm{Br} F$ Ind Med 1990;47:753-62.

167 Wong O, Trent LS, Whorton MD. An updated cohort mortality study of workers exposed to styrene in the reinforced plastics and composites industry. Occup Environ Med 1994;51:386-96.

168 Kogevinas M, Ferro G, Andersen A, Bellander T, Biocca M, Coggon D. Cancer mortality in a historical cohort $\mathrm{M}$, Coggon $\mathrm{D}$. Cancer mortality in a historical cohort study of workers exposed to
Environ Health 1994;20:251-61.

169 Axelson O, Andersson K, Hogstedt C, Holmberg B, Molina G, de Verdier A. A cohort study on trichloroethylene exposure and cancer mortality. $\mathcal{F}$ Occup Med 1978 20:194-6.

170 Axelson O, Seldén A, Andersson K, Hogstedt C. Updated and expanded Swedish cohort study of trichloroethylene and cancer risk. f Occup Med 1994;36:556-62.

171 Beaumont J. Breslow NE. Power considerations in epidemiologic studies of vinyl chloride workers. $A m \mathcal{F}$ Epidemiol 1981;114:725-34.

$172 \mathrm{Ad}$ Hoc Committee of the American Society of Anesthesiologists on the Effect of Trace Anesthetics on the Health of Operating Room Personnel. Occupational disease among operating room personnel: a nationa study. Anesthesiology 1974;41:321-40.

173 Hunter DJ, Colditz GA, Stampfer MJ, Rosner B, Willet WC, Speizer FE. Risk factors for basal cell carcinoma in a prospective cohort of women. Ann Epidemiol 1990;1: a prospec $13-23$.

174 Stevens RG. Electric power use and breast cancer: a hypothesis. Am $\mathcal{F}$ Epidemiol 1987;125:556-61.

175 Demers PA, Thomas DB, Rosenblatt KA, Jimenez LM McTiernan A, Stalsberg H. Occupational exposure to electromagnetic fields and breast cancer in men. $A m$ Epidemiol 1991;134:340-7.

176 Matanoski GM, Breysse PN, Elliott EA. Electromagnetic field exposure and male breast cancer. Lancet 1991; 337:737.

177 Loomis DP. Cancer of breast among men in electrical occupations. Lancet 1992;339:1482-3.

178 Tynes T, Andersen A, Langmark F. Incidence of cancer in Norwegian workers potentially exposed to electromagnetic fields. Am $₹$ Epidemiol 1992;136:81-8

179 Labrèche F, Goldberg MS. Female breast cancer and occupational exposure to organic solvents: an hypothesis. Presented at the 10th International Symposium on Epidemiology in Occupational Health. Como, Italy: 1994

180 International Agency for Research on Cancer. Overal evaluations of carcinogenicity: an updating of IARC monographs volumes 1 to 42 . In: IARC Monographs on the Evaluation of Carcinogenic Risks to Humans. Lyon, France: IARC, 1987;suppl 7.

181 Integrated Risk Information System, US Environmental Protection Agency. Springfield, VA: National Technical Information Service, 1994

182 Siemiatycki J, Day NE, Fabry J, Cooper, JA. Discovering carcinogens in the occupational environment: a nove approach. $\mathcal{F}$ Natl Cancer Inst 1981;66:217-25.

183 Trichopolous $\mathrm{D}$. Are electric or magnetic fields affecting mortality from breast cancer in women? [Editorial] Natl Cancer Inst 1994;86:885-6.

184 Alderson MR, Meade TW. Accuracy of diagnosis on death certificates compared with that in hospital records. Brf Prev Soc Med 1967;21:22-9.

185 de Faire U, Friberg L, Lorich U, Lundman T. A validation of cause-of-death certification in 1156 deaths. Acto Med Scand 1976;20:223-8.

186 Engel LW, Strauchen JA, Chiazze Jr L, Heid M. Accuracy of death certification in an autopsied population with specific attention to malignant neoplasms and vascula diseases. Am f Epidemiol 1980;111:99-112.

187 Percy C, Stanek III E, Gloeckler L. Accuracy of cancer death certificates and its effect on cancer mortality statistics. Am ₹ Public Health 1981;71:242-50.

188 Dewar R, Siemiatycki J, Gérin M. Loss of statistical power associated with the use of a job-exposure matrix in occupational case-control studies. Appl Occup Environ Hyg pational case-cont

189 Arrighi HM, Hertz-Picciotto I. The evolving concept of the healthy worker survivor effect. Epidemiology 1994;5: 189-96

190 Andrews LS, Snyder R. Toxic effects of solvents and vapors. Chapter 20. In: Amdur MO, Doull J, Klaasse $\mathrm{CD}$, eds. Casarett and Doull's toxicology. The basic science of poisons. 4th ed, New York: McGraw-Hill Inc., 1991.

191 Petralias S, Vena JE, Freudenheim J, Marshall J, Swanson M, Graham S. Lifetime occupation and breast cancer. Epidemiology 1995;6:S131.

192 Gérin M, Siemiatycki J, Kemper H, Bégin D. Obtaining occupational exposure histories in epidemiologic casecontrol studies. $\mathcal{F}$ Occup Med 1985;27:420-6.

193 Stewart WF, Stewart PA Occupational case-control studies: I. Collecting information on work histories and work-related exposures. Am $\mathcal{f}$ Ind Med 1994;26: 297-312.

194 Stewart PA, Stewart WF. Occupational case-control studies: II. Recommendations for exposure assessment. $\mathrm{Am}$ F Ind Med 1994;26:313-26. 